\title{
PENGARUH STRATEGI STORY MAPS TERHADAP KETERAMPILANMENULIS CERPEN SISWA KELAS IX SMP YAYASAN HARAPAN IBU
}

\author{
Septi Piani ${ }^{1}$,Yenni Puspita ${ }^{2}$, Hetilaniar $^{3}$ \\ Septipiani@gmail.com \\ Universitas PGRI Palembang
}

\begin{abstract}
Abstrak : Tujuan penelitian ini untuk mengetahui Pengaruh Strategi Story Maps Terhadap Keterampilan Menulis Cerpen Siswa Kelas IX SMP Yayasan Harapan Ibu. Teknik yang digunakan dalam penelitian ini adalah Posttes-Only Control Design dengan menggunakan tes akhir pada kelas eksperimen berjumlah 30 siswa dan kelas kontrol berjumlah 30 siswa. Teknik pengumpulan data menggunakan teknik tes, teknik wawancara. Diperoleh nilai tes akhir kelas eksperimen rata-rata 83,20 . Nilai akhir rata-rata kelas kontrol adalah 73,36. Hal ini diperoleh dari hasil hitungan secara statistik pada uji $\mathrm{t}$, hasil $\mathrm{t}_{\text {hitung }}=5,480$ dengan $\mathrm{dk}=29$ pada taraf signifikan $0,05 \%$ sehingga $\mathrm{dk}=2,04$ jadi $\mathrm{t}_{\text {hitung }} \geq \mathrm{t}_{\text {tabel }}=5,480 \geq 2,04$ sehingga $\mathrm{t}_{\text {hitung }}$ dinyatakan signifikan. Dapat dinyatakan Ho ditolak Ha diterima, yang berarti pengaruh yang signifikan strategi pembelajaran story maps terhadap keterampilan menulis cerpen. Selanjutnya pada uji homogenitas variabel penelitian diketahui nilai Levene Statistic sebesar 0,05, sedangkan nilai signifikan lebih besar dari 0,05 yaitu sebesar 0,060. Karena harga sig > 0,05 maka hipotesis yang menyatakan bahwa data diperoleh dari populasi yang homogen. Dengan demikian hipotesis yang peneliti kemukakan adalah "Terdapat Pengaruh Strategi Story Maps Terhadap Keterampilan Menulis Cerpen Siswa Kelas IX SMP Yayasan Harapan Ibu" terbukti kebenarannya.
\end{abstract}

Kata kunci :Story Maps, Cerpen, posttes-only control design

\begin{abstract}
The purpose of this study was to determine the effect of the Story Maps Strategy on Short Story Writing Skills for Class IX Students of Harapan Ibu Foundation Middle School. The technique used in this research is Posttest-Only Control Design by using a final test in the experimental class totaling 30 students and the control class totaling 30 students. Data collection techniques using test techniques, interview techniques.The average final test score for the experimental class was 83.20. The final score for the control class is 73.36. This is obtained from the results of statistical calculations on the test declared significant. It can be stated that Ho is rejected and $\mathrm{Ha}$ is accepted, which means that there is a significant effect of story maps learning strategies on short story writing skills. Furthermore, in the homogeneity test of the research variables, it is known that the Levene Statistic value is 0.05 , while the significant value is greater than 0.05 , which is 0.060 . Because the price sig $>0.05$, the hypothesis which states that the data is obtained from a homogeneous population. Thus, the hypothesis that the researcher put forward is "There is an Influence of Story Maps Strategy on Short Story Writing Skills for Class IX Students of Harapan Ibu Foundation Middle School" is proven to be true.
\end{abstract}


Keywords : Story Maps, Short Stories, Posttest-only control design.

Artikel Diterima:27-06-2021 Artikel Disetujui:26-07-2021 Artikel Dipublikasi:20-08-2021 Corresponden Author: Desti Mahareta E-mail: destimahareta@gmail.com DOI: http://dx.doi.org/10.31851/pembahsi.v11i12.6201

PENDAHULUAN

Bahasa Indonesia memiliki 4 komponen berbahasa yaitu, keterampilan menyimak, keterampilan berbicara, keterampilan membaca dan keterampilan menulis. Heru, (2018) Menulis merupakan sebuah proses kreatif menuangkan gagasan dalam bentuk bahasa tulis dalam tujuan, misalnya memberi tahu, meyakinkan, atau menghibur Menurut Nofita et al., (2019)menjelaskan menulis adalah suatu rangkaian praktis; di dalamnya termasuk tujuan, prosedur, proses strategi serta cara pembelajaran tentang menulis, tingkah laku, juga bentuk tulisan.

Cerita pendek (cerpen) mempunyai kedudukan sebagai karya sastra yang berbentuk cerita atau narasi (bukan analisis argumentatif) yang fiktif (tidak benar-benar terjadi)(Agustina \& Mardiana, 2019), tetapi dapat terjadi kapan saja dan di mana saja serta relatif pendek. Cerpen sebagai produk budaya senantiasa mengkomunikasikan sejumlah pengalaman batiniah manusia berupa problematik kemanusian yang lahir dari pengarang sebagai pencipta karya sastra dinamis Sundana et al.,( 2017) Cerpen merupakan salah satu jenis karya sastra yang merupakan kisah atau cerita mengenai manusia beserta seluk beluknya lewat tulisan pendek dan singkat. Cerita pendek biasanya mempunyai kata yang kurang dari 10.000 kata dan tidak lebih dari 10 halaman dan hanya memberikan kesan tunggal yang demikian memusatkan diri pada satu tokoh dan hanya satu situasi saja. Kenyataan yang ada di sekolah bahwa banyak siswa yang masih kurang dalam menulis cerpen hal tersebut terlihat ketika peneliti melakukan wawancara dengan guru Bahasa Indonesia di SMP Yayasan Harapan Ibu, juga dengan beberapa siswa kelas IX.

Peneliti memilih menerapkan strategi Story Maps dalam pembelajaran menulis cerpen siswa kelas IX SMP Yayasan Harapan Ibu 
karena strategi Story Maps dimaksudkan untuk membangkitkan semangat dan minat siswa dalam menulis cerpen, selain itu mengajarkan siswa dalam berapresiasi terhadap kemampuan menulis cerpen. Story Maps dapat membantu siswa dalam mencatat, mengingat, meningkatkan pemahaman atas cerpen yang di baca(Strachan \& Mitchell, 2014). Dengan penerapan model ini siswa dapat aktif dalam menulis cerpen dengan pembelajaran memilih makna dari pengalaman secara langsung yang pernah mereka alami dengan pemetaan sehingga akan lebih mudah dan dapat menumbuhkan minat siswa dalam beraktivitas.

\section{METODE}

Metode penelitian eksperimen adalah sebagai metode penelitian yang digunakan untuk mencari pengaruh perlakuan tertentu terhadap yang lain dalam kondisi yang terkendalikan Metode yang digunakan dalam penelitian ini adalah metode Posttes-Only Control Design
Dalam penelitian ini terdapat dua kelompok yang masing-masing dipilih secara Random (R). kelompok

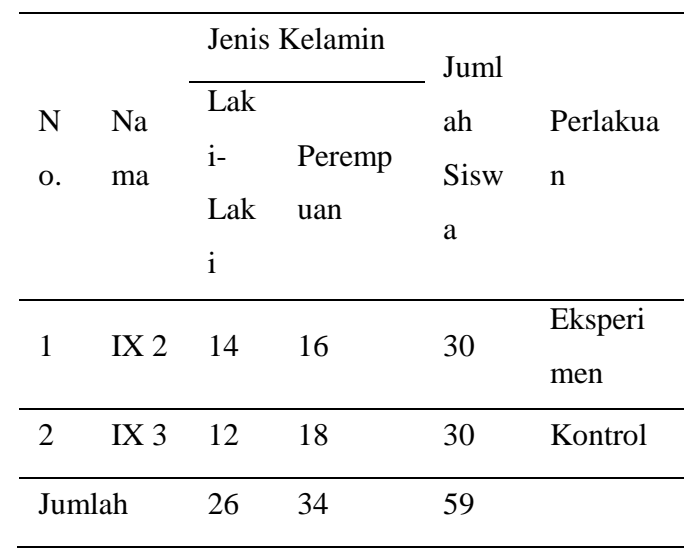

pertama diberi perlakuan (x) disebut kelompok eksperimen dan kelompok yang tidak diberi perlakuan (treatment)(M. Sugiyono, 2015)

Populasi adalah wilayah generalisasi yang terdiri atas: objek/subjek yang mempunyai kualitas dan karakteristik tertentu yang ditetapkan oleh peneliti untuk dipelajari dan kemudian ditarik kesimpulannya. 


\begin{tabular}{ccccc}
\hline \multirow{2}{*}{ No } & & \multicolumn{2}{c}{ Jenis Kelamin } & \\
\cline { 3 - 4 } & Nama & Laki & Jumla \\
& & - & Perempu & h \\
& & Laki & an & \\
\hline 1 & IX 1 & 14 & 16 & 30 \\
\hline 2 & IX 2 & 14 & 16 & 30 \\
\hline 3 & IX 3 & 12 & 18 & 30 \\
\hline 4 & IX 4 & 14 & 15 & 29 \\
\hline 5 & IX 5 & 12 & 18 & 30 \\
\hline JUMLAH & 65 & 84 & 149 \\
\hline \multicolumn{4}{c}{ POPULASI PENELITIAN }
\end{tabular}

Sumber data: kepala tata usaha IX SMP Yayasan Harapan Ibu Tahun Pelajaran 2019/2020.

Bila populasi besar dan peneliti tidak mungkin mempelajari semua yang ada pada populasi. (D. Sugiyono, 2013) sampel yang diambil dari populasi harus representatif (mewakili). Maka dari itu sampel yang digunakan peneliti adalah sampel Random dengan acak memilih kelas kontrol dan kelas Eksperimen dengan dilaksanakan secara mengundi.

Sumber Data: Hasil Pengolahan Data Sampel

Terdapat dau hal utama yang mempengaruhi kualitas data hasil penelitian yaitu, kualitas instrument penelitian, dan kualitas pengumpulan data. Metode pengumpulan data ialah teknik atau cara-cara yang dapat digunakan oleh peneliti untuk mengumpulkan data(Riduwan, 2002). Penelitian menggunakan Teknik Tes dan Wawancara dengan menggunakan alat perekam Tape recorder.

\section{HASIL DAN PEMBAHASAN}

Penelitian ini dilakukan di SMP yayasan harapan ibu, terdiri dari kelas eksperimen yang berjumlah 30 orang siswa dan kelas kontrol yang terdiri dari 30 orang siswa. Dalam pelaksanaannya sebelum menerapkan strategi story maps peneliti terlebih dahulu melakukan observasi pada kelas eksperimen atau kelas yang akan diberi perlakuan, kelas eksperimen adalah kelas IX-1 yang jumlah siswanya 30 orang 22 perempuan dan 8 laki-laki, penelitian ini dilakukan sebanyak 2 kali pertemuan untuk setiap kelas dan pertemuan ketiga merupakan tes akhir di kedua kelas.

Dari hasil analisis yang dilakukan oleh peneliti dengan cara melihat hasil menulis cerpen siswa kelas eksperimen, setelah di terapkan 
strategi story maps siswa mendapatkan hasil yang lebih baik dibandingkan dengan kelas kontrol yang hanya menggunakan metode konvensional atau ceramah.

Hal ini diketahui dari nilai rata-rata siswa kelas eksperimen yaitu 84,1 , sedangkan nilai rata-rata kelas kontrol yaitu 71.7 Berdasarkan hasil nilai Tes tersebut diperoleh bahwa nilai kelompok eksperimen lebih tinggi disbandingkan dengan nilai kelompok control. Selanjutnya peneliti melakukan analisis data tes dengan menggunakan uji-t yang terdiri dari uji normalitas data, uji homogenitas data dan uji hipotesis data. Uji normalitas data dilakukan untuk mengetahui normal atau tidaknya suatu penyebaran data, lalu uji homogenitas dilakukan untuk membuktikan persamaan varians kelompok yang membentuk sampul dan uji hipotesis untuk menyatakan tentang parameter tingkat signifikat data. Berdasarkan perhitungan yang di peroleh untuk kelas eksperimen Kolmogorov-Smirnov uji normalitas data signifikan dari kelas eksperiman sebesar 0,240 dan kelas control 0,135 . Karena harga signifikan lebih besar dari 0,05 (sig > 0,05), maka data sampel berasal dari populasi yang terdistribusi normal.

Kemudian untuk uji homogenitas data diperoleh nilai Levene Statistic sebesar 0,060, sedangkan nilai signifikan lebih besar dari 0,05 yaitu sebesar 0,060. sehingga dapat disimpulkan bahwa sampel berasal dari populasi yang sama jadi, penelitian ini di kelas eksperimen ataupun kelas kontrol mengikuti distribusi normal dan homogeny. Setelah pengujian normalitas dan homogenitas data dilakukan, data tersebut dinyatakan terdistribusi normal dan varians dalam penelitian bersifat homogen maka tahapan berikutnya dilanjutkan dengan uji hipotesis penelitian menggunakan Paired Samples Test yaitu rumus uji-t SPSS 25 dengan keriteria pengujian dengan kriteria pengujian adalah menerima $\mathrm{H} 0$ apabila harga ${ }^{\mathrm{t}}$ hitung $>$ dari ${ }^{\mathrm{t}}$ tabel pada taraf signifikan $0,05$. . Berdasarkan analisis data mengenai hasil belajar siswa melalui uji-t maka diperoleh nilai $\mathrm{t}_{\text {hitung }}=5,480 \mathrm{t}_{\text {tabel }}$ $=2,04$ dari perhitungan $t_{\text {hitung }}>$ $\mathrm{t}_{\text {tabel }}$ maka Ha diterima. 
Dengan demikian, kelas eksperimen yang menggunakan strategi story maps menunjukkan adanya perkembangan kemampuan dibanding kelas kontrol yang tidak diberi perlakuan khusus. Hal ini sejalan dengan kajian terdahulu yang relevan yaitu hasil belajar siswa mencapai 100\%.Dengan hasil pada tahap I $85 \%$ dan tahap II $100^{\wedge} \%$. Maka ada peningkatan yang sangat signifikan terhadap hasil belaar yang di terapkan strategi story maps. Berdasarkan wawancara guru kelas IX SMP Yayasan Harapan Ibu. Dapat diketahui bahwa guru sudah memberikan materi menulis cerpen. Ada siswa yang sudah mampu menulis cerpen, namun ada juga yang belum mampu menulis cerpen. Setelah melakukan penelitian dengan strategi story maps. kemampuan siswa dalam menulis cerpen mengalami peningkatan hal ini terlihat dari data hasil belajar siswa. Dan terbukti dari nilai rata-rata tes akhir siswa pada kelas eksperimen 84,1 sedangkan di kelas kontrol 71,7 yang telah di bahas sebelumnya. Hasil penelitian ini menunjukkan bahwa pembelajaran strategi story maps terhadap kemampuan menulis cerpen siswa kelas IX SMP Yayasan Harapan Ibu mempengaruhi hasil belajar. Oleh karena itu, strategy story maps dapat diterapkan dalam pembelajaran menulis cerpen.

\section{KESIMPULAN}

Berdasarkan hasil penelitian yang berjudul, "Pengaruh Strategi Story Maps Terhadap Keterampilan Menulis Cerpen Siswa Kelas IX SMP Yayasan Harapan Ibu" dapat disimpulkan bahwa penggunaan manfaat strategi story maps memberikan pengaruh yang positif terhadap kemampuan menulis cerpen siswa kelas IX SMP Yayasan Harapan Ibu Palembang Tahun pelajaran 2020/2021.

Hal ini dibuktikan pada hasil $\mathrm{T}_{\text {hitung }}>$ dari pada $\mathrm{T}_{\text {tabel }}=5,480>$ 2,04 sehingga $\mathrm{T}_{\text {hitung dinyatakan }}$ signifikan, Dengan demikian. dapat dinyatakan hipotesis nol $\left(\mathrm{H}_{0}\right)$ dalam penelitian ini ditolak dan hipotesis $\left(\mathrm{H}_{a}\right)$ diterima. Berdasarkan hasil wawancara dapat disimpulkan bahwa jawaban wawancara relevan dengan hasil tes menulis cerpen siswa. Hal ini juga didukung oleh seluruh data 
hasil dari penelitian yang menyatakan bahwa penggunaan strategi story maps memiliki pengaruh yang positif dan keseluruhan, keaktifan siswa. Berdasarkan uraian hasil penelitian dan pembahasan di atas, penulis ingin memberikan saran-saran sebagai berikut.

a. Guru, hendaknya menggunakan strategi story maps dalam penyampaian materi Bahasa Indonesia terutama dalam keterampilan menulis cerpen.

b. Siswa, diharapkan dapat lebih mempersiapkan diri dalam menerima materi, terutama dalam menyaipkan sarana yang akan digunakan

Peneliti lain, hendaknya menjadikan penelitian ini sebagai informasi dan masukan sekaligus acuan dalam melakukan penelitian sejenis.

\section{DAFTAR PUSTAKA}

Agustina, J., \& Mardiana, M. (2019). Pengaruh film indie (independent) terhadap keterampilan menulis cerpen siswa kelas xi sma negeri 1 talang kelapa. Jurnal Pembahsi (Pembelajaran
Bahasa Dan Sastra Indonesia), 9(2), 159-166.

Heru, A. (2018). Pengaruh Penggunaan Media Gambar Terhadap Menulis Karangan Deskripsi. Wahana Didaktika: Jurnal Ilmu Kependidikan, 16(1), 29-34.

Nofita, A., Hasani, A., \& Mawadah, A. H. (2019). Hubungan kecerdasan kinestetik dan penguasaan kalimat efektif dengan keterampilan menulis teks ulasan karya siswa kelas VIII SMPN 7 Kota Serang tahun ajaran 2018/2019. Jurnal Membaca Bahasa Dan Sastra Indonesia, 4(2).

Riduwan, M. (2002). Metode Dan Teknik Penyusunan Tesis. Alphabet, Bandung.

Strachan, C., \& Mitchell, J. (2014). Teachers' perceptions of Esri Story Maps as effective teaching tools. Review of International Geographical Education Online, 4(3), 195220.

Sugiyono, D. (2013). Metode penelitian pendidikan pendekatan kuantitatif, kualitatif dan $R \& D$.

Sugiyono, M. (2015). Penelitian \& pengembangan (Research and Development/R\&D). Bandung: Penerbit Alfabeta.

Sundana, L., Harun, M., \& Idham, M. (2017). Kearifan Lokal Masyarakat Aceh Dalam Kumpulan Cerpen Melalui 
PEMBAHSI JURNAL PEMBELAJARAN BAHASA INDONESIA Volume 11, No. 2 Tahun 2021

Ilusi Waktu Karya

Musmarwan Abdullah. JIM

Pendididikan Bahasa Dan

Sastra Indonesia, 2(2), 151166. 